\title{
Altered Postnatal Lung Development in C3H/HeJ Mice
}

\author{
VENKATESH SAMPATH, KATY DAVIS, ALBERT P. SENFT, THERESA R. RICHARDSON, JOSEPH A. KITZMILLER, \\ PIERRE YVES BERCLAZ, AND THOMAS R. KORFHAGEN
}

Division of Pulmonary Biology, Cincinnati Children's Hospital Medical Center, Cincinnati, Ohio 45229

\begin{abstract}
C} 3 \mathrm{H} / \mathrm{HeJ}$ mice develop an increase in terminal air space area detectable by postnatal d 14 that persists into adulthood compared with strain-matched controls $(\mathrm{C} 3 \mathrm{H} / \mathrm{SnJ}, \mathrm{C} 3 \mathrm{H} / \mathrm{OuJ})$. Morphometric quantification revealed a $50 \%$ increase in terminal air space area by postnatal d 14 and a 2.3 -fold increase by 2 mo of age in $\mathrm{C} 3 \mathrm{H} / \mathrm{HeJ}$ mice. Bacteriologic cultures obtained from the left lung on postnatal d 7 revealed $>100$ colony-forming units (CFU)/left lung of predominantly Gram-negative bacteria (GNB) (Escherichia coli and Proteus mirabilis) in 13 of the $14 \mathrm{C} 3 \mathrm{H} / \mathrm{HeJ}$ mice compared with 0 of 12 controls demonstrating colonization of the developing lung in $\mathrm{C} 3 \mathrm{H} / \mathrm{HeJ}$ mice. An approximately threefold increase in macrophages from bronchoalveolar lavage, threefold increases in matrix metalloproteinase 12 (MMP-12) mRNA and protein levels and elevated levels of proinflammatory cytokines monocyte chemoattractant protein (MCP-1) and keratinocyte-derived cytokine (KC) were also found. $P$. mirabilis obtained from lung cultures in $\mathrm{C} 3 \mathrm{H} / \mathrm{HeJ}$ mice induced nuclear factor- $\kappa \mathrm{B}(\mathrm{NF}-\kappa \mathrm{B})$ activation in human embryonic kidney 293 (HEK 293) cells transfected with TLR5. In C3H/HeJ mice lacking TLR4 signaling, bacterial colonization is associated with chronic inflammation and permanent changes in lung morphology. (Pediatr Res 60: 663-668, 2006)
\end{abstract}

$\mathrm{B}$ ronchopulmonary dysplasia (BPD) is an important cause of morbidity and mortality in preterm infants, affecting $40 \%$ of all infants born with a birth weight $<1000 \mathrm{~g}(1)$. The routine use of antenatal steroids, surfactant, and gentler ventilation strategies has led to the emergence of the "new" BPD, which predominantly affects extremely low birth weight infants $(2,3)$ who despite requiring minimal or no ventilatory support still progress to BPD $(3,4)$. Lung pathology in these infants reveals large, simplified alveolar structures and abnormalities in microvasculature development with variable interstitial cellularity (5). Although BPD is a multifaceted disease, lung infections have been implicated in the pathogenesis of BPD $(6,7)$. Ureaplasma urealyticum, Gram-positive bacteria, and GNB frequently colonize lungs of the premature infant and have been associated with BPD (6-9). The underlying mechanisms by which bacterial colonization of the immature lung can result in morphologic changes seen in BPD have not been elucidated.

Mice are born with lungs in the saccular phase of development; alveolarization is initiated around postnatal d 5 and is

Received March 24, 2006; accepted July 19, 2006.

Correspondence: Thomas R. Korfhagen, M.D., Ph.D., Division of Pulmonary Biology, Cincinnati Children's Hospital Medical Center, 3333 Burnet Avenue, Cincinnati, OH 45229; e-mail: korft0@cchmc.org

Supported by grant HL 58795 from.

DOI: $10.1203 / 01 . p d r .0000246071 .50268 .51$ completed in the first 2-3 wk of life (10). Because lung development in mice parallels that in preterm infants who are born with their lungs in late canalicular or early saccular phase (11), mice can serve as a model of the developing premature human lung. It is well established that the preterm infant is at increased risk of infections because various components of the immune system are not well developed $(12,13)$. Decreased expression of innate host defense molecules might alter susceptibility to bacterial colonization and chronic inflammation leading to morphologic changes in the lung architecture characteristic of BPD.

Mammalian Toll-like receptors are pattern recognition receptors (PRRs) that interact with pathogen-associated molecular patterns and serve as the recognition and effector arm of the innate immune response $(14,15)$. Toll-like receptor 4 (TLR4) serves as a PRR for GNB by recognizing lipopolysaccharide (LPS) (16) and mediating LPS responsiveness (17). Studies in adult mice lacking TLR4 signaling have shown that this receptor is essential for clearance of GNB $(18,19) . \mathrm{C} 3 \mathrm{H} / \mathrm{HeJ}$ mice have a naturally occurring missense mutation in the cytoplasmic domain of TLR4 abolishing responsiveness to LPS (17). In the present study, we demonstrated that $\mathrm{C} 3 \mathrm{H} / \mathrm{HeJ}$ mice get colonized with bacteria in the lung and develop a chronic inflammatory process and lung pathology characterized by large alveolar spaces similar to those of BPD.

\section{MATERIALS AND METHODS}

Mice. The Animal Care and Use Committee at the Cincinnati Children's Hospital Research Foundation approved the mouse studies. C3H/HeJ and control mice $(\mathrm{C} 3 \mathrm{H} / \mathrm{OuJ}, \mathrm{C} 3 \mathrm{H} / \mathrm{SnJ}$, and $\mathrm{C} 3 \mathrm{H} / \mathrm{HeN})$ mice were obtained from Jackson Laboratories. Mice were maintained in static micro-isolator cages without forced air flow. Cage changes were weekly. Routine serologic testing did not detect viruses. Although cage litter is autoclaved, mice are not maintained in a germ-free environment and are exposed to commensal bacteria. Different aged mice were generated by inbreeding.

Estimation of terminal air space area. Three to four lungs, each from $\mathrm{C} 3 \mathrm{H} / \mathrm{HeJ}$ and controls $(\mathrm{C} 3 \mathrm{H} / \mathrm{SnJ})$, were collected at $14 \mathrm{~d}, 1 \mathrm{mo}$, and $2 \mathrm{mo}$ and from $\mathrm{C} 3 \mathrm{H} / \mathrm{OuJ}$ mice at 2 mo of age. Two serial sections per mouse were obtained and stained with hematoxylin and eosin. Three representative fields of lung, each containing $>100$ terminal air spaces were studied per slide. Fields with large conducting airways, longitudinal sections of alveolar ducts, or blood vessels were not selected. Measurements were collected using Image-1/Metamorph Imaging system; version 2 for Microsoft Windows

Abbreviations: HEK 293, human embryonic kidney 293; KC, keratinocytederived cytokine; LPS, lipopolysaccharide; MCP-1, monocyte chemoattractant protein; MMP-12, matrix metalloproteinase 12 
(Universal Imaging Corp., 1994) as previously described (20). Briefly, the images captured at $10 \times$ were thresholded for air space and terminal air space area obtained by dividing the total air space per image in square microns $\left(\mu \mathrm{m}^{2}\right)$ by number of terminal air spaces.

Estimation of lung volumes. Lungs from 8-wk-old $\mathrm{C} 3 \mathrm{H} / \mathrm{HeJ}$ and control mice $(n=4)$ were inflated with $4 \%$ paraformaldehyde in $1 \times$ phosphatebuffered saline (PBS) at $25 \mathrm{~cm} \mathrm{H}_{2} \mathrm{O}$ for $1 \mathrm{~min}$, and after $24 \mathrm{~h}$ in fixative, lung volumes were determined by the volume displacement method described by Scherle (21).

Bronchoalveolar lavage (BAL). After euthanasia, the trachea was cannulated, lungs lavaged three times with $1 \mathrm{~mL}$ of PBS, and samples pooled. Cells were collected by centrifugation, resuspended in $100 \mu \mathrm{L}$ of PBS and $5 \mu \mathrm{L}$ mixed with $5 \mu$ l trypan blue $(0.4 \%)$, and counted on a hemocytometer. The volume of the BAL fluid was brought to $1 \mathrm{~mL}$ with PBS, and differential counts were performed on Diff-Quick stained (Baxter Diagnostics, McGraw Park, IL) cytospins of cells (Cytospin 3, Shandon Scientific).

Protein studies for MMP-12. Lung homogenates in $1 \mathrm{~mL}$ of PBS containing protease inhibitors were centrifuged at $1500 \times g$, and supernatants stored at $-70^{\circ} \mathrm{C}$. For Western blot analysis, $30 \mu \mathrm{g}$ of protein was separated on a $4 \%-12 \%$ Tris-glycine gel, membranes blocked in 5\% fat-free milk in Tris buffered saline plus tween (TBS-T) $(1 \mathrm{~h})$, rinsed in TBS-T, and incubated with primary antibody (1:750 in 5\% milk in TBS-T) overnight. After three washes in TBS-T, the blot was incubated in horseradish peroxidaseconjugated secondary antibody for $1 \mathrm{~h}$, washed, and developed using ECL reagent (Amersham). The anti-MMP-12 antibody (Biomol, Cal) detects both active and inactive forms of mouse MMP-12 (22). Bands were captured using PC Image and normalized for $\beta$-actin using Image Quant 5.2.

Lung cytokine assays. MCP-1, KC, tumor necrosis factor (TNF) $\alpha$, interleukin (IL)-6, IL-10, and macrophage inflammatory protein-1 alpha (MIP-1 $\alpha$ ) levels were measured from lung homogenates using commercially available enzyme-linked immunosorbent assay (ELISA) kits (R\&D Systems Inc., Minneapolis, MN) according to the manufacturer's recommendations.

Bacterial cultures of whole lung. After euthanasia and after a $70 \%$ alcohol wash, the abdomen was opened and the inferior vena cava transected. Instruments were resterilized, and the thoracic cavity was entered through a sternotomy and dissection of the diaphragm. The left lung was removed with care taken to avoid adnexal structures, placed in $0.5 \mathrm{~mL}$ of sterile PBS, and homogenized, and the dilutions plated in duplicate on sheep blood agar plates.

TLR4, CD14, and MD2 cloning. Mouse TLR4, CD14, and MD2 were amplified from cDNA prepared from MLE-15 RNA using the GC Rich PCR Kit (Roche) for TLR4 and MD2 and Expand Long Template PCR Kit (Roche) for CD14. Primers, specific for mouse TLR4, CD14, and MD2 and including Kozak sequences, were used to prepare polymerase chain reaction (PCR) products that were cloned into pCDNA3.1 Topo (Invitrogen) and confirmed by DNA sequencing.

Transfection experiments with HEK 293 cells. HEK 293 cells were plated at a density of $10^{5}$ cells/well in 24-well plates in minimal essential media (GIBCO) containing 10\% low endotoxin fetal bovine serum. Transfections were performed using Fugene reagent (Roche, MN). The TLR5 expression construct was purchased from Invivogen (San Diego, CA). Colonies of $P$. mirabilis obtained from lungs were grown overnight in 2XYT media, washed, and resuspended in sterile PBS. Fifty microliters of heat-killed P. mirabilis (boiling for $10 \mathrm{~min}$ ) at a concentration of $10^{8} / \mathrm{mL}$ was added to each well for $2 \mathrm{~h}$. Luciferase activation was determined from cell lysates using a luminometer (Berthold, Oakridge, TN). Data are reported as the ratio of luciferase activity of the NF- $\kappa \mathrm{B}-$ dependent pELAM-luc (kind gift of Dr. M. Fenton) to the TK-renilla.

RNA isolation and real-time PCR analysis. Lung tissue was lysed in 4 $\mathrm{mol} / \mathrm{L}$ guanidinium isothiocyanate, $0.5 \%$ laurylsarcosine, and $0.1 \mathrm{~mol} / \mathrm{L}$ $\beta$-mercaptoethanol in $25 \mathrm{mmol} / \mathrm{L}$ sodium citrate buffer (GITC) and RNA reverse-transcribed using a cDNA cycle kit (Invitrogen, Carlsbad, CA). Reaction conditions differed slightly, depending on the primers used, and generally were $95^{\circ} \mathrm{C}$ for $300 \mathrm{~s}$ followed by 40 cycles of amplification $\left(95^{\circ} \mathrm{C}\right.$ for $10 \mathrm{~s}, 60^{\circ} \mathrm{C}$ for $15 \mathrm{~s}$, and $72^{\circ} \mathrm{C}$ for $25 \mathrm{~s}$ ). Amplification product size and forward and reverse primer sequences were as follows: L32 (257 bp) $5^{\prime}$ GTGAAGCCCAAGATCGTC-3' ', '' -AGCAATCTCAGCACAGTAAG-3', MMP-12 (321 bp) 5'- ACAGCATCTTAGAGCAGTGC-3',5' -AGTCCACGTTTCTGCCTCAT- $3^{\prime}$. Measurement of amplified product was made for $6 \mathrm{~s}$ every cycle, and melt curve analyses were performed after every run to ensure that a single amplified product was produced. Relative quantification was obtained by measuring the cycle at which the greatest accumulation of product occurred (cycle threshold) and plotting that against the cycle thresholds of a dilution series of positive control samples.

Statistical methods. Differences in terminal air space areas between strains of mice at different time points were determined using ANOVA with a significance level of 0.05. Differences in cytokines, MMP-12, lung volumes, and macrophages in BAL were estimated using a $t$ test. For differences in bacterial counts, the Mann-Whitney nonparametric test (statistiXL 1.5 for Microsoft Excel) was used. All these analyses were performed using Microsoft Office Excel (Microsoft Office Professional Edition Office 2003).

\section{RESULTS}

C3H/HeJ mice develop enlarged terminal air spaces. Differences in alveolar air space were detected in $\mathrm{C} 3 \mathrm{H} / \mathrm{HeJ}$ compared with $\mathrm{C} 3 \mathrm{H} / \mathrm{SnJ}$ mice at $14 \mathrm{~d}, 1 \mathrm{mo}$, and $2 \mathrm{mo}$ of age and compared with $\mathrm{C} 3 \mathrm{H} / \mathrm{HeN}$ and $\mathrm{C} 3 \mathrm{H} / \mathrm{OuJmice}$ at 1 and 2 mo (Fig. 1). Differences in terminal air space area were not detected at $6 \mathrm{~d}$ of age but were $50 \%$ greater in the $\mathrm{C} 3 \mathrm{H} / \mathrm{HeJ}$ mice when compared with $\mathrm{C} 3 \mathrm{H} / \mathrm{SnJ}$ mice at $14 \mathrm{~d}(p<0.001)$. A twofold increase $(p<0.001)$ in $\mathrm{C} 3 \mathrm{H} / \mathrm{HeJ}$ mice was detected by 1 mo and a 2.3 -fold increase $(p<0.001)$ detected by 2 months (Fig. 2). Terminal air space area differences persisted between $\mathrm{C} 3 \mathrm{H} / \mathrm{HeJ}$ and $\mathrm{C} 3 \mathrm{H} / \mathrm{OuJ}$ mice at 2 mo of age (data not shown).

Lung volumes are increased in $\mathrm{C} 3 \mathrm{~h} / \mathrm{HeJ}$ mice. At 2 mo of age, a $15 \%$ increase in lung volume was detected in $\mathrm{C} 3 \mathrm{H} / \mathrm{HeJ}$ mice when compared with controls $(0.71 \pm 0.01 \mathrm{~mL}$ versus $0.63 \pm 0.01, p<0.001)$. As the increase in terminal air space area was proportionally much greater $(230 \%)$ than the increase in lung volume in $\mathrm{C} 3 \mathrm{H} / \mathrm{HeJ}$ mice, this represents a loss of lung parenchyma with increased air space.

\section{C3H/HeJ}

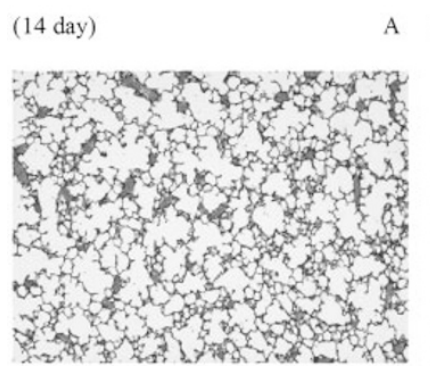

(1 month)

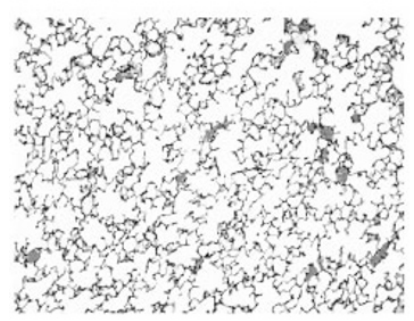

(2 month)

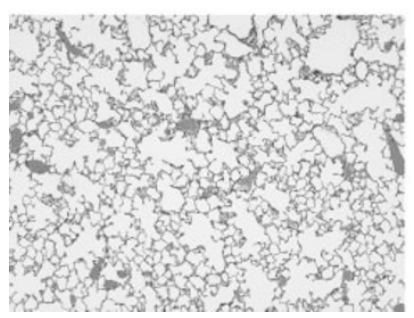

Control

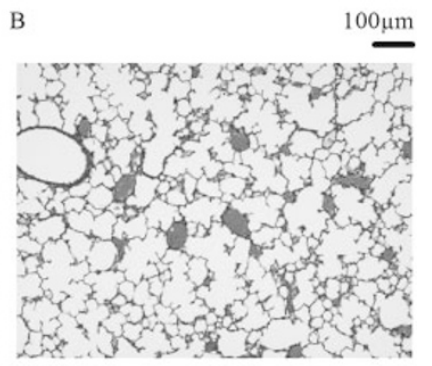

D

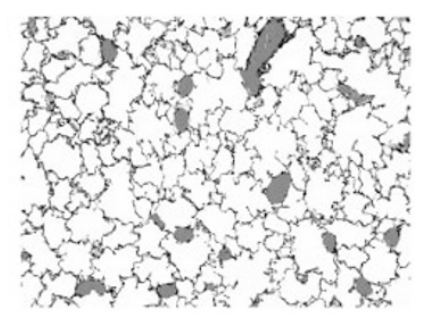

$\mathrm{F}$

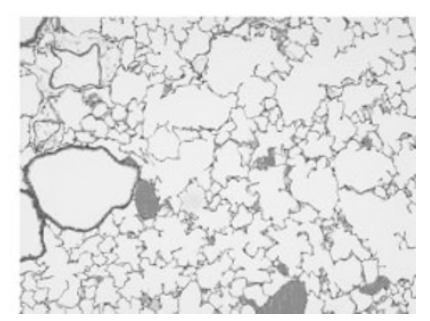

Figure 1. Lung histology of $\mathrm{C} 3 \mathrm{H} / \mathrm{HeJ}$ and control mice showing progressive increase in alveolar air spaces: $A-F$ are representative of four to six individual mice killed at each time point (postnatal age $14 \mathrm{~d}, 1 \mathrm{~m}$, and $2 \mathrm{mo}$ ) (magnification $\times 10$ ). 


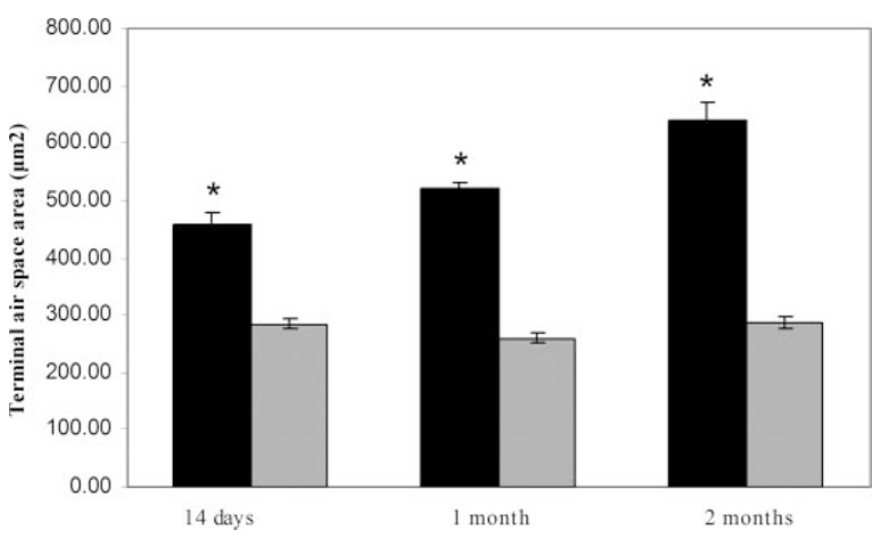

Figure 2. Increased terminal air space area. There was a progressive increase in terminal air space area in $\mathrm{C} 3 \mathrm{H} / \mathrm{HeJ}$ mice (filled columns) expressed in square microns [mean \pm standard error of the mean (SEM)] compared with controls (shaded columns) at postnatal age $14 \mathrm{~d}, 1 \mathrm{mo}$ and 2 mo. Data are representative of three individual mice killed at each time point. ${ }^{*} p<0.001$.

Inflammatory infiltrates in $\mathrm{C} 3 \mathrm{H} / \mathrm{HeJ}$ mouse lung sections. Cellular infiltrates visualized in the $\mathrm{C} 3 \mathrm{H} / \mathrm{HeJ}$ mice on postnatal d 14 persisted at 2 mo of age (Fig. $3 A$ and $B$ ). Inflammatory cells could be seen in the peripheral lung parenchyma, terminal and respiratory bronchioles, and around small vessels. On higher resolution, macrophages constituted the major cell type though neutrophils were also seen at $14 \mathrm{~d}$ of age. Lymphocytes, macrophages, and neutrophils contributed to perivascular cuffing seen at $14 \mathrm{~d}$ of age (Fig. 3C). Mucous hyperplasia visualized in 2-wk-old $\mathrm{C} 3 \mathrm{H} / \mathrm{HeJ}$ mice was most prominent in the large bronchi and occasionally extended into smaller bronchioles (Fig. 3D) but was not detected at 2 mo of age.

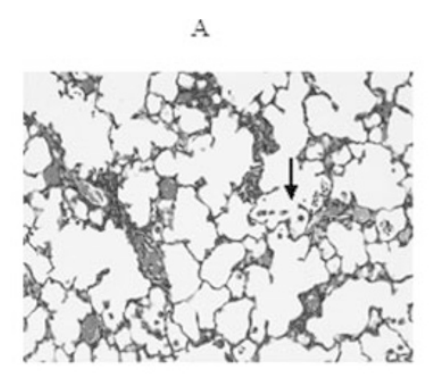

$\mathrm{C}$
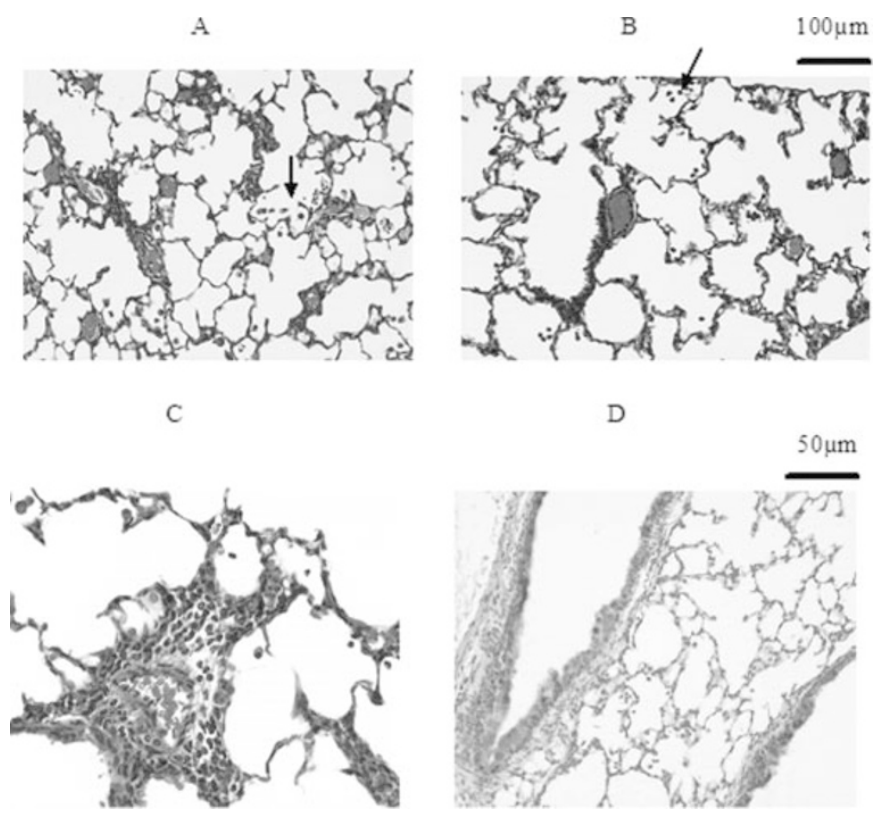

D

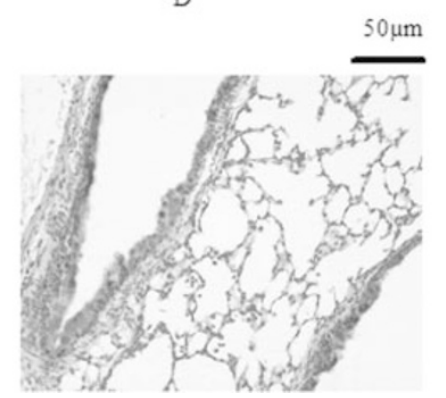

Figure 3. Inflammatory cells in $\mathrm{C} 3 \mathrm{H} / \mathrm{HeJ}$ lungs. $(A)$ Inflammatory cells at $14 \mathrm{~d}$ (marker points to macrophages). (B) Inflammatory cells and increased alveolar spaces at 2 mo of age (marker points to macrophage infiltrate). $(C)$ Perivascular cuffing due to inflammatory infiltrates at $14 \mathrm{~d}$. (D) Alcian blue staining demonstrating goblet cell hyperplasia in bronchi at $14 \mathrm{~d}$. Lung sections are representative of three to four mice killed at each time point. ( $A$ and $B$ : magnification $\times 20 ; C$ and $D$ : magnification $\times 40$.)

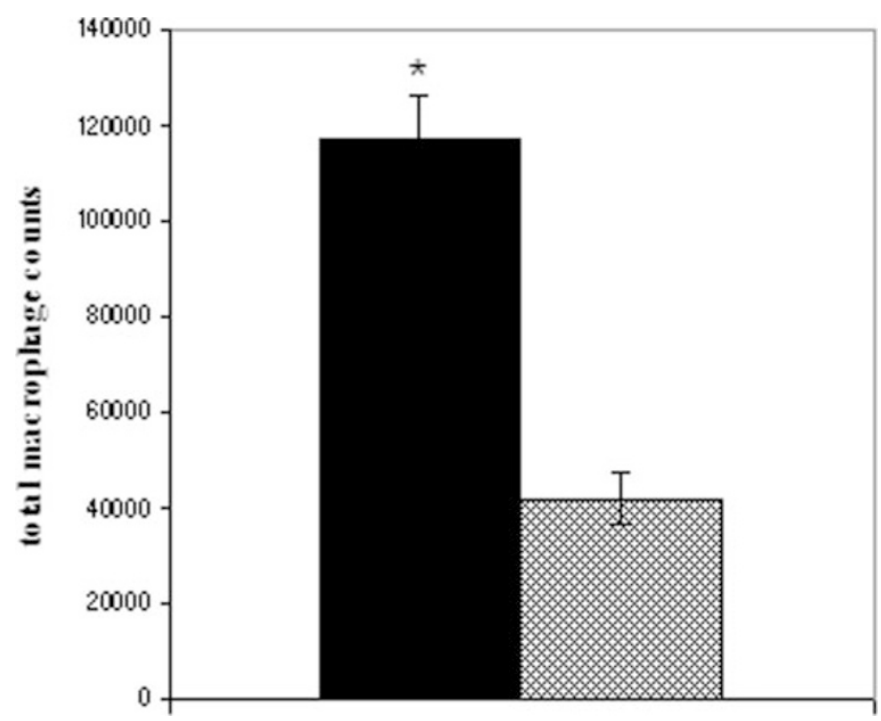

Figure 4. Increased cell counts in BAL. There was an almost threefold increase in cell counts ( $>90 \%$ macrophages) in $\mathrm{C} 3 \mathrm{H} / \mathrm{HeJ}$ mice (filled column) compared with controls (hatched column) at 1 mo of age. Data are expressed as mean \pm SEM and is representative of two different experiments $(n=3$ each). ${ }^{*} p<0.05$.

Increased macrophages in $\mathrm{BAL}$ of $\mathrm{C} 3 \mathrm{H} / \mathrm{HeJ}$ mice. Total cell counts in BAL were approximately threefold higher in $\mathrm{C} 3 \mathrm{H} / \mathrm{HeJ}$ mice compared with controls $(117,167 \pm 9480$ cells/mL versus $41,833 \pm 5543 \mathrm{~mL} p=0.018$ ) (Fig. 4). Differential counts revealed $>90 \%$ macrophages in both the control and $\mathrm{C} 3 \mathrm{H} / \mathrm{HeJ}$ mice. Neutrophils were also increased in the $\mathrm{C} 3 \mathrm{H} / \mathrm{HeJ}$ mice compared with the controls.

MMP-12 mRNA and protein levels are increased in the C3H/HeJ mice. Real-time PCR demonstrated a 3.5-fold increase in MMP-12 mRNA (normalized for ribosomal unit L32) in lung homogenates from $\mathrm{C} 3 \mathrm{H} / \mathrm{HeJ}$ mice compared with controls $(p=0.007)$ at $14 \mathrm{~d}$ of age (Fig. 5A). A greater than threefold increase in a protein migrating at $22 \mathrm{Kd}$ consistent with the active form of MMP-12 (20-22 kD) was detected in $\mathrm{C} 3 \mathrm{H} / \mathrm{HeJ}$ mice on $\mathrm{d} 14(p=0.02)$ by densitometry. At $7 \mathrm{~d}$ of age, there was a 3.6-fold increase in the active form of MMP-12 in C3H/HeJ mice ( $p=0.01$ ) (Fig. $5 B$ ). There were no detectable differences in MMP-9 or -2 on zymograms of lung homogenates (data not shown).

MCP-1 and KC levels are increased in C3H/HeJ mice. There was a greater than threefold increase in the MCP-1 in $\mathrm{C} 3 \mathrm{H} / \mathrm{HeJ}$ mice when compared with controls at 7 and $14 \mathrm{~d}$ of life $(146 \mathrm{pg} / \mathrm{mL}$ versus $45.6 \mathrm{pg} / \mathrm{mL}$ on $\mathrm{d} 7,140.7 \mathrm{pg} / \mathrm{mL}$ versus $42.7 \mathrm{pg} / \mathrm{mL}$ on $\mathrm{d} \mathrm{14,p}=0.03$ and $p=0.007$, respectively). $\mathrm{KC}$ levels in $\mathrm{C} 3 \mathrm{H} / \mathrm{HeJ}$ mice were increased almost fourfold on d 14 (188 pg/mL versus $38.9 \mathrm{pg} / \mathrm{mL}, p<$ $0.0001)$. There was a modest increase in TNF- $\alpha$ levels in $\mathrm{C} 3 \mathrm{H} / \mathrm{HeJ}$ mice on $\mathrm{d} 7$ and 14 ( $p=0.01$ and $p=0.004$ ), respectively, and a trend toward increased MIP- $1 \alpha$ levels in the $\mathrm{C} 3 \mathrm{H} / \mathrm{HeJ}$ mice (Fig. 6). There were no significant differences in IL-10 and IL-6 levels between $\mathrm{C} 3 \mathrm{H} / \mathrm{HeJ}$ mice and controls. There were no differences in IL- $1 \alpha$, IL- $1 \beta$, IL-18, and IL-1Ra as assessed by ribonuclease protection assay at $14 \mathrm{~d}$ of age and IL-13 levels by ELISA at $14 \mathrm{~d}$ of age (data not shown). 


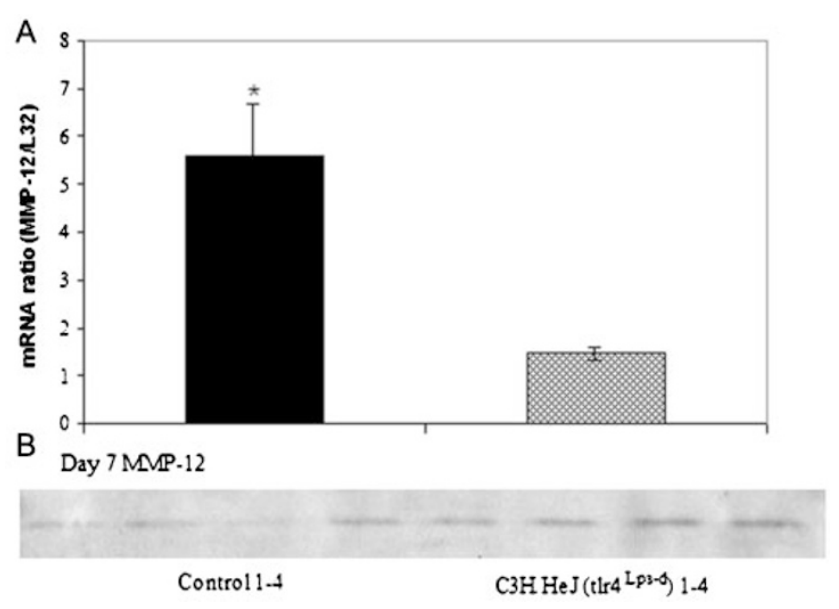

Figure 5. Increased MMP-12 mRNA and protein. (A) Real-time PCR demonstrated a greater than threefold increase in MMP-12 mRNA in $\mathrm{C} 3 \mathrm{H} / \mathrm{HeJ}$ mice (filled column) relative to control mice (hatched column) on postnatal d 14. ${ }^{*} p=0.007$. (B) Western blots for MMP-12 showing increased detection of a band consistent with the active form of MMP-12 (22 kD) in C3H/HeJ mice on postnatal $\mathrm{d} 7$.

Increased bacterial counts in $\mathrm{C} 3 \mathrm{H} / \mathrm{HeJ}$ lungs. For 7-d-old animals, three experiments from different litters at three different time points were done. Of the $14 \mathrm{C} 3 \mathrm{H} / \mathrm{HeJ}$ mice studied, 13 had $>100 \mathrm{CFU} / \mathrm{mL}$ of bacteria in the left lung, with a range between 150 and 204,000 CFU/mL (Table 1). Of the 12 control mice killed on $\mathrm{d} 7$, none of the lungs had bacterial counts $>100 \mathrm{CFU} / \mathrm{mL}$, and only three mice had bacteria $(10,20$, and $60 \mathrm{CFU} / \mathrm{mL})$. These differences in bac-
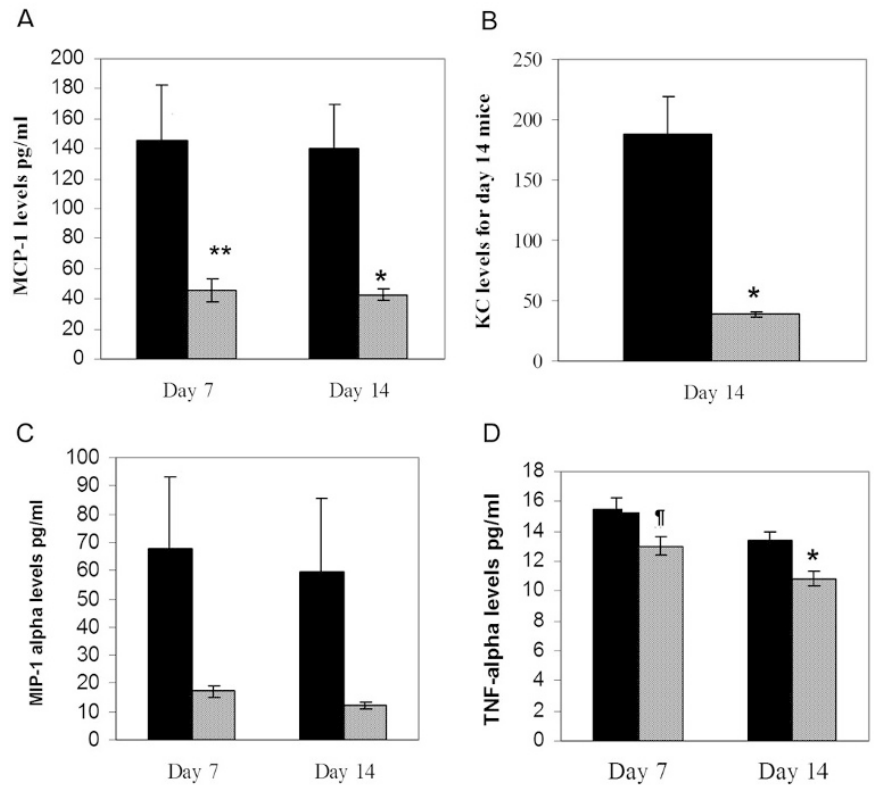

Figure 6. Increased MCP-1 and KC levels. Lung cytokine levels were determined by ELISA on postnatal $\mathrm{d} 7$ and 14. Data are expressed as mean \pm SEM and represents two separate sets of mice ( $n=3-4$ each). (A) MCP-1 levels are increased by more than threefold in $\mathrm{C} 3 \mathrm{H} / \mathrm{HeJ}$ mice (filled columns) compared with controls (shaded columns). $* * p=0.03 ; * p=0.007$. (B) KC levels are increased by $>3.5$-fold in $\mathrm{C} 3 \mathrm{H} / \mathrm{HeJ}$ mice (filled columns) compared with controls (shaded columns), ${ }^{*} p=0.007$. (C) MIP- $1 \alpha$ was increased in $\mathrm{C} 3 \mathrm{H} / \mathrm{HeJ}$ mice when compared with controls, but this did not reach significance. (D) TNF- $\alpha$ levels were increased by about $20 \%$ in $\mathrm{C} 3 \mathrm{H} / \mathrm{HeJ}$ mice (filled columns) when compared with controls (shaded columns), I $p=0.01 ; * p=0.004$.
Table 1. GNB colonize lungs in 7-d old C3H/HeJ mice

\begin{tabular}{|c|c|c|c|c|c|}
\hline Exp. & $\begin{array}{l}\text { Mouse } \\
\text { strain }\end{array}$ & CFU/lung & Bacteria & $\begin{array}{l}\text { Mouse } \\
\text { strain }\end{array}$ & CFU/lung \\
\hline \multirow[t]{6}{*}{$1^{*}$} & HeJ\#1 & 60,000 & $100 \%$ E. coli & $\mathrm{HeN \# 1}$ & 0 \\
\hline & HeJ\#2 & 17,800 & $\begin{array}{c}\text { 3\% Streptococcus, } \\
97 \% \text { E. coli }\end{array}$ & $\mathrm{HeN \# 2}$ & 0 \\
\hline & HeJ\#3 & 1360 & $\begin{array}{c}50 \% \text { E. coli, } 50 \% \\
\text { Streptococcus }\end{array}$ & $\mathrm{HeN \# 3}$ & 0 \\
\hline & HeJ\#4 & 21,600 & $\begin{array}{c}80 \% \text { P. mirabilis, } \\
20 \% \text { E. coli }\end{array}$ & $\mathrm{HeN \# 4}$ & 20 \\
\hline & HeJ\#5 & 2610 & $100 \%$ E. coli & & \\
\hline & HeJ\#6 & 10,300 & $\begin{array}{l}93 \% \text { E. coli, } 7 \% \\
\text { P. mirabilis }\end{array}$ & & \\
\hline \multirow[t]{4}{*}{$2 \dagger$} & HeJ\#1 & 2780 & $\begin{array}{c}50 \% \text { P. mirabilis } \\
50 \% \text { E. coli }\end{array}$ & $\mathrm{HeN \# 1}$ & 0 \\
\hline & HeJ\#2 & 100 & $100 \%$ P. mirabilis & $\mathrm{HeN \# 2}$ & 0 \\
\hline & HeJ\#3 & 500 & $\begin{array}{c}90 \% \text { P. mirabilis } \\
10 \% \text { E. coli }\end{array}$ & $\mathrm{HeN \# 3}$ & 0 \\
\hline & HeJ\#4 & 0 & No colonies & HeN\#4 & 0 \\
\hline \multirow[t]{4}{*}{$3 \ddagger c$} & HeJ\#1 & 28,000 & $>95 \%$ P. mirabilis & HeN\#1 & 0 \\
\hline & HeJ\#2 & 204,000 & $>95 \%$ P. mirabilis & $\mathrm{HeN \# 2}$ & 10 \\
\hline & HeJ\#3 & 60,000 & $>95 \%$ P. mirabilis & HeN\#3 & 60 \\
\hline & HeJ\#4 & 8800 & $>95 \%$ P. mirabilis & $\mathrm{HeN \# 4}$ & 0 \\
\hline
\end{tabular}

Bacterial cultures done from left lung homogenates on postnatal $\mathrm{d} 7$ in $\mathrm{C} 3 \mathrm{H} / \mathrm{HeJ}$ mice revealed that $13 / 14$ of $\mathrm{C} 3 \mathrm{H} / \mathrm{HeJ}$ mice had $>100 \mathrm{CFU} / \mathrm{left}$ lung of GNB (P. mirabilis and E. coli) compared to 0 of 13 of control mice $(p<$ 0.001). Bacteria were estimates based on colonial morphology after identification of species. Data shown are representative of three different experiments with bacterial counts expressed in CFU/left lung.

$$
\begin{aligned}
& * p=0.01 . \\
& \dagger p=0.03 . \\
& \ddagger p=0.03 .
\end{aligned}
$$

terial counts were statistically significant for each individual experiment and highly significant cumulatively ( $p \ll 0.001$ ). Approximately $85 \%$ of the bacteria cultured were GNB, predominantly $P$. mirabilis and E. coli. Similar experiments conducted at $14 \mathrm{~d}$ and $1 \mathrm{mo}$ did not consistently reveal bacterial colonization.

$P$. mirabilis induces NF- $\mathrm{KB}$ activity through TLR5 in the absence of TLR4. Heat-killed $P$. mirabilis stimulated a sixfold increase in NF- $\kappa$ B activity in HEK 293 cells transfected with TLR4/CD14/MD2 and >12-fold increase with HEK 293 cells transfected with TLR5 (Fig. 7). NF- $\kappa$ B activity was significantly increased compared with transfected, but not stimulated, HEK 293 cells $(p \ll 0.0001$ and $p=0.0005$ for TLR4/CD14/MD2 and TLR5, respectively). Induction of NF- $\kappa$ B activity in TLR5 transfected HEK 293 cells was twofold greater than in TLR4/CD14/MD2 transfected HEK 293 cells $(p=0.0045)$. As a control, a heat-killed $E$. coli isolate from the lungs of the $\mathrm{C} 3 \mathrm{H} / \mathrm{HeJ}$ mice induced NF- $\kappa \mathrm{B}$ about 80-fold compared with an un-induced TLR5 in HEK cells $(p<0.0007$, two experiments with triplicate wells for each condition). These data demonstrate that $P$. mirabilis cultured from $\mathrm{C} 3 \mathrm{H} / \mathrm{HeJ}$ mouse lung can stimulate NF- $\kappa \mathrm{B}$ activity through TLR5 independently of TLR4.

\section{DISCUSSION}

$\mathrm{C} 3 \mathrm{H} / \mathrm{HeJ}$ mice with a loss of function mutation in TLR4 signaling (17) develop morphologic changes consistent with BPD associated with bacterial colonization and chronic in- 


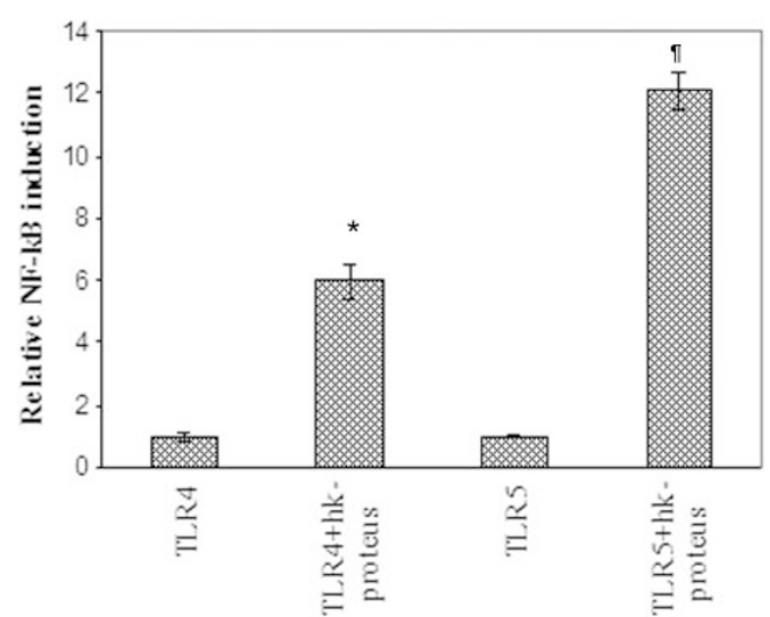

Figure 7. $P$. mirabilis induces NF- $\kappa \mathrm{B}$ through TLR5. Heat-killed $P$. mirabilis induced about sixfold increases in NF- $\kappa \mathrm{B}$ activity in HEK 293 cells transfected with TLR4/CD14/MD2 $(* p<0.0001)$ and $>12$-fold increase in HEK 293 cells transfected with TLR5 ( $\llbracket p=0.0005)$. Data are reported as the ratio of luciferase activity of the NF- $\kappa \mathrm{B}$-dependent pELAM-luc to the TK-renilla. Data presented are representative of three experiments done at different time points with triplicate wells for each experimental condition.

flammation. The bacterial load and species were variable. Although $\mathrm{C} 3 \mathrm{H} / \mathrm{HeJ}$ mice have been previously noted to have increased alveolar spaces when compared with C57/BL6 and AJ mice, the etiology of increased air spaces has been attributed to strain differences (23). To our knowledge, distal air spaces in $\mathrm{C} 3 \mathrm{H}$ substrains have not been reported. Morphologic changes in the $\mathrm{C} 3 \mathrm{H} / \mathrm{HeJ}$ mice were not demonstrable during the first week of life, and the subsequent changes were coincident with bacterial colonization and inflammation.

Although TLR4 signaling is essential for clearance of GNB in experimental models of pneumonia in adult mice $(18,19,24)$, the present study demonstrates a potential role for TLR4 in preventing bacterial colonization in the developing lung of the $\mathrm{C} 3 \mathrm{H}$ strain. In the cage system of our vivarium, immature mice are exposed to various bacteria in the litter and their excreta, but the absence of TLR4 signaling results in a significantly greater transient bacterial colonization of lungs in the $\mathrm{C} 3 \mathrm{H} / \mathrm{HeJ}$ strain compared with controls. The presence of live bacteria during alveolar development may result in disrupted lung development. Additionally, exposure to bacterial products could result in disrupted development. It is not possible to be certain of the relative contribution of the TLR4 deficiency and the bacterial colonization. Development of strain-matched mice in a germ-free environment would be necessary to eliminate exposure to either live bacteria or bacterial products. However, similar associations between bacterial colonization and BPD have been reported in premature infants (7-9). Cordero et al. (9) demonstrated that $36 \%$ of preterm infants mechanically ventilated for $14 \mathrm{~d}$ were colonized with GNB including E. coli, and these infants were twice as likely to develop BPD compared with infants without GNB colonization.

Bacterial colonization of the $\mathrm{C} 3 \mathrm{H} / \mathrm{HeJ}$ mice was associated temporally with elevated macrophage counts and increased MMP-12 levels in the lung. MMP-12 is a member of the matrix-degrading proteinase (MMPs) family and is the pri- mary elastase enzyme of the macrophage (25). MMP-12 is required for macrophage-mediated proteolysis and matrix invasion in mice (26), has been associated with lung remodeling in SP-D and TIMP-3 knockout mice (27), and is essential in the pathogenesis of smoke-induced emphysema in mice (28). Thus, in the $\mathrm{C} 3 \mathrm{H} / \mathrm{HeJ}$ mice, elevated MMP-12 levels might contribute to the altered postnatal lung development.

MCP-1 is a chemokine for monocytes produced by macrophages, lymphocytes, and alveolar epithelial cells in response to inflammatory stimuli $(29,30)$. MCP-1 and its receptor CCR2 are thought to play a role in multiple lung inflammatory disorders (29). The increased MCP-1 levels in $\mathrm{C} 3 \mathrm{H} / \mathrm{HeJ}$ mice may account for the increased macrophages seen on lung histology and by BAL. KC is a chemokine for neutrophils and with MIP-2 is considered to be the functional analogue of human IL-8 $(31,32)$. The increased expression of $\mathrm{KC}$ in $\mathrm{C} 3 \mathrm{H} / \mathrm{HeJ}$ mice results in early neutrophil influx and subsequent inflammation. Multiple investigators have demonstrated increased levels of MCP-1 and IL-8 from tracheal aspirates of ventilated preterm infants who subsequently developed BPD $(33,34)$.

Inflammation in the absence of TLR4 signaling in $\mathrm{C} 3 \mathrm{H} / \mathrm{HeJ}$ mice suggests that other TLRs might be involved in the inflammatory response to GNB. Although other authors have reported that $E$. coli signaling through TLR5 is necessary and sufficient to stimulate production of IL-8 from enterocytes (35), in this study, we have demonstrated that $P$. mirabilis obtained from lung cultures in $\mathrm{C} 3 \mathrm{H} / \mathrm{HeJ}$ stimulated NF- $\kappa \mathrm{B}$ activity in HEK 293 cells via TLR5. Moreover, in C3H/HeJ mice, intraperitoneal injection of Salmonella dublin flagellin resulted in shock and later death similar to $\mathrm{C} 3 \mathrm{H} / \mathrm{OuJ}$ controls (36). Even in the absence of TLR4 signaling, GNB colonization could induce cytokine production through TLR5, resulting in chronic inflammation seen in the $\mathrm{C} 3 \mathrm{H} / \mathrm{HeJ}$ mice. Although not tested in the present study, bacterial breakdown products (CpG-oligodeoxynucleotides) through TLR9 might also play a role in the inflammation in the lungs of $\mathrm{C} 3 \mathrm{H} / \mathrm{HeJ}$ mice.

While the ontogeny of expression of Toll proteins in the human lung has not been established, in mice, TLR4 is expressed in the fetal lung by embryonic d 14-15, increases several folds till birth, and expression in the adult lung is much higher than in the newborn (37). If expression of TLR4 in the human lung mimics the mouse lung, then the preterm human lung might be considered to have deficient TLR4 signaling. This could increase their susceptibility to bacterial colonization/infection, resulting in inflammation and BPD. Although BPD is a multifaceted disease, deficiencies in innate host defense molecules may contribute to pathogenesis of this disease.

\section{REFERENCES}

1. Stevenson DK, Wright LL, Lemons JA, Oh W, Korones SB, Papile LA, Bauer CR, Stoll BJ, Tyson JE, Shankaran S, Fanaroff AA, Donovan EF, Ehrenkranz RA, Verter J 1998 Very low birth weight outcomes of the National Institute of Child Health and Human Development Neonatal Research Network January 1993 through December 1994. Am J Obstet Gynecol 179:1632-1639

2. O'Brodovich HM, Mellins RB 1985 Bronchopulmonary dysplasia: unresolved neonatal acute lung injury. Am Rev Respir Dis 132:694-709 
3. Bancalari E, Gonzalez A 2000 Clinical course and lung function abnormalities during development of neonatal lung disease. In: Bland RD, Coalson JJ (eds) Chronic Lung Disease in Early Infancy. Marcel Dekker, New York, pp 41-64.

4. Charafeddine L, D’Angio CT, Phelps DL 1999 Atypical chronic lung disease patterns in neonates. Pediatrics 103:759-765

5. Husain AN, Siddiqui NH, Stocker JT 1998 Pathology of arrested acinar development in post- surfactant bronchopulmonary dysplasia. Hum Pathol 29:710-717

6. Young KC, Del Moral T, Claure N, Vanbuskirk S, Bancalari E 2005 The association between early tracheal colonization and bronchopulmonary dysplasia. J Perinatol 25:403-407

7. Kotecha S, Hodge R, Schaber JA, Miralles R, Silverman M, Grant WD 2004 Pulmonary Ureaplasma urealyticum is associated with the development of acute lung inflammation and chronic lung disease in preterm infants. Pediatr Res 55:61-68

8. Papoff P, Fiorucci P, Ficuccilli F, Giustiniani D, Mancuso M, Lorusso G, Donato AI, Colarizi P 1997 Characteristics of airway colonization in mechanically ventilated newborn infants. Pediatr Med Chir 19:413-416

9. Cordero L, Ayers LW, Davis K 1997 Neonatal airway colonization with gramnegative bacilli: association with severity of bronchopulmonary dysplasia. Pediatr Infect Dis J 16:18-23

10. Amy RW, Bowes D, Burri PH, Haines J, Thurlbeck WM 1977 Postnatal growth of the mouse lung. J Anat 124:131-151

11. Burri PH 1997 Structural Aspects of Prenatal and Postnatal Development and Growth of the Lung. Marcel Dekker, New York, pp 1-35

12. Koenig JM, Yoder MC 2004 Neonatal neutrophils: the good, the bad, and the ugly. Clin Perinatol 31:39-51

13. Levy O 2005 Innate immunity of the human newborn: distinct cytokine responses to LPS and other Toll-like receptor agonists. J Endotoxin Res 11:113-116

14. Lemaitre B, Nicolas E, Michaut L, Reichhart JM, Hoffmann JA 1996 The dorsoventral regulatory gene cassette spatzle/Toll/cactus controls the potent antifungal response in Drosophila adults. Cell 86:973-983

15. O'Neill LA, Greene C 1998 Signal transduction pathways activated by the IL-1 receptor family: ancient signaling machinery in mammals, insects, and plants. J Leukoc Biol 63:650-657

16. Beutler B 2000 Tlr4: central component of the sole mammalian LPS sensor. Curr Opin Immunol 12:20-26

17. Poltorak A, He X, Smirnova I, Liu MY, Van Huffel C, Du X, Birdwell D, Alejos E, Silva M, Galanos C, Freudenberg M, Ricciardi-Castagnoli P, Layton B, Beutler B 1998 Defective LPS signaling in $\mathrm{C} 3 \mathrm{H} / \mathrm{HeJ}$ and $\mathrm{C} 57 \mathrm{BL} / 10 \mathrm{ScCr}$ mice: mutations in Tlr4 gene. Science 282:2085-2088

18. Branger J, Knapp S, Weijer S, Leemans JC, Pater JM, Speelman P, Florquin S, van der Poll T 2004 Role of Toll-like receptor 4 in gram-positive and gram-negative pneumonia in mice. Infect Immun 72:788-794

19. Faure K, Sawa T, Ajayi T, Fujimoto J, Moriyama K, Shime N, Wiener-Kronish JP 2004 TLR4 signaling is essential for survival in acute lung injury induced by virulent Pseudomonas aeruginosa secreting type III secretory toxins. Respir Res 5:1-10

20. Hardie WD, Piljan-Gentle A, Dunlavy MR, Ikegami M, Korfhagen TR 2001 Dosedependent lung remodeling in transgenic mice expressing transforming growth factor-alpha. Am J Physiol Lung Cell Mol Physiol 281:L1088-L1094

21. Scherle W 1970 A simple method for volumetry of organs in quantitative stereology. Mikroskopie 26:57-60
22. Lang R, Kocourek A, Braun M, Tschesche H, Huber R, Bode W, Maskos K 2001 Substrate specificity determinants of human macrophage elastase (MMP-12) based on the 1.1 A crystal structure. J Mol Biol 312:731-742

23. Soutiere SE, Tankersley CG, Mitzner W 2004 Differences in alveolar size in inbred mouse strains. Respir Physiol Neurobiol 140:283-291

24. Higgins SC, Lavelle EC, McCann C, Keogh B, McNeela E, Byrne P, O’Gorman B, Jarnicki A, McGuirk P, Mills KH 2003 Toll-like receptor 4-mediated innate IL-10 activates antigen-specific regulatory $\mathrm{T}$ cells and confers resistance to Bordetella pertussis by inhibiting inflammatory pathology. J Immunol 171:3119-3127

25. Shapiro SD, Griffin GL, Gilbert DJ, Jenkins NA, Copeland NG, Welgus HG, Senior RM, Ley TJ 1992 Molecular cloning, chromosomal localization, and bacterial expression of a murine macrophage metalloelastase. J Biol Chem 267:4664-4671

26. Shipley JM, Wesselschmidt RL, Kobayashi DK, Ley TJ, Shapiro SD 1996 Metalloelastase is required for macrophage-mediated proteolysis and matrix invasion in mice. Proc Natl Acad Sci U S A 93:3942-3946

27. Mahadeva R, Shapiro SD 2002 Chronic obstructive pulmonary disease * 3: Experimental animal models of pulmonary emphysema. Thorax 57:908-914

28. Hautamaki RD, Kobayashi DK, Senior RM, Shapiro SD 1997 Requirement for macrophage elastase for cigarette smoke-induced emphysema in mice. Science 277:2002-2004

29. Rose CE Jr, Sung SS, Fu SM 2003 Significant involvement of CCL2 (MCP-1) in inflammatory disorders of the lung. Microcirculation 10:273-288

30. Lu B, Rutledge BJ, Gu L, Fiorillo J, Lukacs NW, Kunkel SL, North R, Gerard C, Rollins BJ 1998 Abnormalities in monocyte recruitment and cytokine expression in monocyte chemoattractant protein 1-deficient mice. J Exp Med 187:601-608

31. Bozic CR, Gerard NP, von Uexkull-Guldenband C, Kolakowski LF Jr, Conklyn MJ, Breslow R, Showell HJ, Gerard C 1994 The murine interleukin 8 type B receptor homologue and its ligands. Expression and biological characterization. J Biol Chem 269:29355-29358

32. Watanabe K, Konishi K, Fujioka M, Kinoshita S, Nakagawa H 1989 The neutrophil chemoattractant produced by the rat kidney epithelioid cell line NRK-52E is a protein related to the KC/gro protein. J Biol Chem 264:19559-19563

33. Baier RJ, Majid A, Parupia H, Loggins J, Kruger TE 2004 CC chemokine concentrations increase in respiratory distress syndrome and correlate with development of bronchopulmonary dysplasia. Pediatr Pulmonol 37:137-148

34. Baier RJ, Loggins J, Kruger TE 2001 Monocyte chemoattractant protein-1 and interleukin-8 are increased in bronchopulmonary dysplasia: relation to isolation of Ureaplasma urealyticum. J Investig Med 49:362-369

35. Bambou JC, Giraud A, Menard S, Begue B, Rakotobe S, Heyman M, Taddei F, Cerf-Bensussan N, Gaboriau-Routhiau 2004 In vitro and ex vivo activation of the TLR5 signaling pathway in intestinal epithelial cells by a commensal Escherichia coli strain. J Biol Chem 279:42984-42992

36. Eaves-Pyles T, Murthy K, Liaudet L, Virag L, Ross G, Soriano FG, Szabo C, Salzman AL 2001 Flagellin, a novel mediator of Salmonella-induced epithelial activation and systemic inflammation: I kappa B alpha degradation, induction of nitric oxide synthase, induction of pro-inflammatory mediators, and cardiovascular dysfunction. J Immunol 166:1248-1260

37. Harju K, Ojaniemi M, Rounioja S, Glumoff V, Paananen R, Vuolteenaho R, Hallman M 2005 Expression of toll-like receptor 4 and endotoxin responsiveness in mice during perinatal period. Pediatr Res 57:644-648 